\title{
Nutrient digestion, ruminal fermentation and performance of dairy cows fed pomegranate peel extract
}

\author{
M.J. Abarghuei ${ }^{\text {a }}$, Y. Rouzbehan ${ }^{\text {a,* }}$, A.Z.M. Salem ${ }^{\text {b,c }}$, M.J. Zamiri ${ }^{\mathrm{d}}$ \\ a Animal Science Department, Faculty of Agriculture, Tarbiat Modares University, P.O. Box 14115-336, Tehran, Iran \\ ${ }^{\mathrm{b}}$ Facultad de Medicina Veterinariay Zootecnia, Universidad Autónoma del Estado de México, México \\ ${ }^{\mathrm{c}}$ Faculty of Agriculture, Alexandria University, Alexandria, Egypt \\ ${ }^{\mathrm{d}}$ Department of Animal Science, College of Agriculture, Shiraz University, Shiraz, Iran
}

\section{A R T I C L E I N F O}

\section{Article history:}

Received 17 February 2013

Received in revised form

19 August 2013

Accepted 11 September 2013

Keywords:

Dairy cow

Milk

Protozoa

Ruminal parameters

\begin{abstract}
A B S T R A C T
An experiment was carried out to determine the effect of pomegranate peel extract (PPE) on nutrient digestion, ruminal fermentation characteristics, protozoal population and performance of dairy cows. Four Holstein cows were used in a $4 \times 4$ Latin square design with 28-d periods and 4 treatments: PPE0 (no extract), PPE400 (400 ml PPE/cow/d), PPE800 (800 ml PPE/cow/d) and PPE1200 (1200 ml PPE/cow/d). Intake of dry matter, milk yield, and digestibility of dry matter, organic matter, crude protein, neutral detergent fiber and acid detergent fiber were measured. Ruminal fermentation characteristics such as ruminal $\mathrm{pH}$, concentration of $\mathrm{NH}_{3}-\mathrm{N}$, concentration of VFA, molar proportions of individual VFA, protozoa population and microbial $\mathrm{N}$ were also measured. Milk production, 4\% FCM yield, milk fat and protein yield $(\mathrm{kg} / \mathrm{d})$, and milk efficiency were increased by inclusion of PPE800 in the diet. Percent of milk fat, true protein, and lactose were not affected by PPE supplementation. However, inclusion of PPE decreased $\mathrm{NH}_{3}-\mathrm{N}$, total protozoal population, genus Isotricha and Entodinium, but increased microbial $\mathrm{N}$ production $(\mathrm{g} / \mathrm{d})$. Concentrations of total VFA and molar proportions of individual VFA were not affected by inclusion of PPE in the diet. The results suggested that PPE supplementation has reduced protozoa population, $\mathrm{NH}_{3}$-Nconcentration, and increased microbial protein and milk yield and quality.
\end{abstract}

(c) 2013 Elsevier B.V. All rights reserved.

\section{Introduction}

Dry climatic condition and shortage of water resources in many countries, has led to a scarcity in the quantity and

\footnotetext{
Abbreviations: ADFom, ash-free acid detergent fiber; AIA, acid detergent insoluble ash; $\mathrm{BW}$, body weight; $\mathrm{CP}$, crude protein; $\mathrm{CT}$, condensed tannin; DM, dry matter; HT, hydrolysable tannins; ME, metabolizable energy; $\mathrm{N}$, nitrogen; $\mathrm{NE}_{\mathrm{L}}$, net energy for lactation; $\mathrm{NDFom}$, ash-free neutral detergent fiber; NTP, non-tannin phenol; OM, organic matter; PD, purine derivates; PPE, pomegranate peel extract; PSM, Plant secondary metabolites; PVPP, polyvinylpyrrolidone; SP, saponin; TMR, total mix ration; TP, total phenols; TT, total tannin; VFA, volatile fatty acids

* Corresponding author. Tel.: +98 21 48292336; fax: +982148292200.

E-mail addresses: rozbeh_y@modares.ac.ir, faranakuk@yahoo.com (Y. Rouzbehan).
}

quality of consistent year-round supply of conventional ruminant feeds (Abarghuei et al., 2010). Consequently, the prices of animal feed, particularly protein supplements, become more costly. Yet, some common supplements, such as soybean meal, are metabolized less efficiently (i.e., losses of $\mathrm{NH}_{3}-\mathrm{N}$ ) in the rumen (Van Nevel and Demeyer, 1988) resulting in decreased animal performance and contributing to environmental pollution (Tamminga and Hobson, 1996). Thus, much research has been carried out to enhance the efficiency of protein metabolism and maximize the growth performance and economic viability of livestock operations. Plant secondary metabolites (PSM) in tree leaves such as Salix babylonica, Leucaenaleucocephala, and grape pomace extracts (Alipour and Rouzbehan, 2010; Jiménez-Peralta et al., 2011; Salem et al., 2011) were found to have a positive effect on ruminal fermentation parameters and to increase 
Table 1

Ingredients and chemical composition (means \pm SD) of the TMR fed to lactating cows $(n=4)$.

\begin{tabular}{ll}
\hline Ingredients (g/kg DM) & \\
\hline Alfalfa hay & 229.0 \\
Corn silage & 211.9 \\
Barley, rolled & 134.5 \\
Corn grain, ground, dry & 81.9 \\
Wheat bran & 99.4 \\
Wheat grain, rolled & 27.7 \\
Soybean meal, 44\% CP & 66.3 \\
Canola meal & 28.0 \\
Cottonseed meal & 39.3 \\
Vegetable oil & 12.4 \\
Limestone & 6.2 \\
Mineral+ vitamin premix ${ }^{\mathrm{a}}$ & 12.4 \\
Salt & 6.2 \\
Molasses, beet sugar & 14.5 \\
Sodium bicarbonate & 12.4 \\
Fish meal & 17.0 \\
Chemical composition (g/kg of DM) & \\
DM & $603 \pm 3.5$ \\
OM & $926 \pm 4.6$ \\
CP & $160 \pm 7.6$ \\
NDF & $340 \pm 2.5$ \\
ADF & $201 \pm 1.2$ \\
NE (Mcal/kg) & $1.57 \pm 0.009$ \\
\hline
\end{tabular}

Estimated from NRC (2001).

a Contained 196 g Ca, 96 g P, 71 g Na, 19 g Mg, 3 g Fe, 0.3 g Cu, 2 g Mn, $3 \mathrm{~g} \mathrm{Zn}, 100 \mathrm{ppm}$ Co, 100 ppm I, $0.1 \mathrm{ppm}$ Se and $50 \times 10^{5}$ IU vitamin A, $10 \times 10^{5} \mathrm{IU}$ vitamin D and $0.1 \mathrm{~g}$ vitamin $\mathrm{E} / \mathrm{kg}$

amino acid flow to the duodenum (Mueller-Harvey, 2006). This could lead to more muscle deposition and greater milk production (Vasta et al., 2008).

Pomegranate peel (PP) is a by-product of extracting the juice from pomegranates, with annual production of more than 120,000 t in Iran (Mirzaei-Aghsaghali et al., 2011). The PP contains secondary metabolites such as saponin, polyphenolic compounds, primarily punicalagin and ellagitannins, which have been shown to possess antimicrobial, antioxidant, anti-inflammatory, antimitotic, and immune modulatory properties (Adams et al., 2006; Oliveira et al., 2010). Bacterial predation by protozoa has the most deleterious effect on the efficiency of $\mathrm{N}$ use in the rumen. The PP contains saponins which may improve $\mathrm{N}$ efficiency by decreasing protozoal activity (Hess et al., 2004). Therefore, we hypothesized that inclusion of PP extract (PPE) to the diet would enhance ruminal microbial protein synthesis and increase milk protein content.

Oliveira et al. (2010) found that feeding a pomegranate extract to young calves for the first $70 \mathrm{~d}$ of life decreased intake of grains and whole tract digestibility of fat and crude protein, likely because of its high tannin content. However, Jami et al. (2012) and Shabtay et al. (2012) noted a significant increase in the digestibility of dry matter, crude protein, and neutral detergent fiber, as well as milk and energy-corrected milk yields in cows fed $4 \%$ pomegranate-peel extract supplement. The inconsistency between these studies may be ascribed to differences in pomegranate type (i.e., the concentration and nature of the active ingredients), extracting method the age of animals which affect animal performance. Commonly, extraction of the secondary metabolites is carried out using solvents, such as methanol, ethanol or acetone (Makkar, 2003), which is to some extent costly. Therefore, there is a need to investigate the effectiveness of less costly techniques at the farmer's level. Water can be used for extraction purposes because it is cheap and easy to handle. Hence, this experiment was carried out to assess the influence of three levels of PPE, extracted by water, on ruminal fermentation characteristics, protozoal population, microbial protein synthesis, nutrient digestibility and performance in dairy cows.

\section{Materials and methods}

\subsection{Animal care}

The experiment was carried out according to The Care and Use of Agricultural Animals in Research and Teaching (FASS, 2010) guidelines. All procedures and guidelines involving animals were approved by the Animal Experiment Committee at Tarbiat Modares University (Tehran, Iran).

\subsection{Pomegranate peel extract}

Pomegranate peel was obtained from two main factories in Saveh city, using similar pomegranate varieties and processing methods. Sun-dried peel was extracted at $1 \mathrm{~g} \mathrm{PP} / \mathrm{ml}$ of water. The peel was soaked in tap water at $40{ }^{\circ} \mathrm{C}$ for $72 \mathrm{~h}$ in a closed tank. To maximize the extraction of PSM (Table 2) from the PP, the tank was incubated in a water bath at $40{ }^{\circ} \mathrm{C}$ for one more hour. The contents, then, were immediately filtered and the filtrate was stored at $4{ }^{\circ} \mathrm{C}$ for further use.

\subsection{Experimental design, cows and treatments}

The experiment was designed as a balanced $4 \times 4$ Latin square for carryover effects, using 4 dairy cows with four 28 -d periods. The cows in three lactations averaged $87 \pm 29$ DIM at the start of the experiment with a mean BW of $616 \pm 53 \mathrm{~kg}$. They were housed in individual tie stalls and had free access to water during the experiment. A TMR (Table 1) was fed for ad libitum intake (5-10\% orts, on as-fed basis). The animals were randomly assigned to 1 of 4 treatments: (1) PPE0 (control, no PPE added), (2) PPE400 (400 ml PPE/cow per day), (3) PPE800 (800 ml PPE/cow per day), and (4) PPE1200 (1200 ml PPE/cow per day). The PPE was extracted daily. Each experimental period lasted $28 \mathrm{~d}$ with $2 \mathrm{~d}$ for adaptation to the diet, and $7 \mathrm{~d}$ for sampling and data collection. All diets were formulated to have similar concentrations of $\mathrm{CP}$ and $\mathrm{NE}_{\mathrm{L}}$ (NRC, 2001).

\subsection{Feed intake, body weight and nutrient digestibility}

Diets were offered in equal amounts 3 times daily (0600, $1400 \mathrm{~h}$ and, $2200 \mathrm{~h}$ ). Feed consumption was recorded daily by weighing feeds offered to and refused by the cows. Samples of the TMR, feed ingredients, and orts were 
collected daily and kept frozen. Samples were composited by period, dried at $55{ }^{\circ} \mathrm{C}$ for $48 \mathrm{~h}$, ground through a $1-\mathrm{mm}$ screen Wiley mill (standard model 4; Arthur M. Thomas, Philadelphia, PA, US). Fecal grab samples were collected from all cows about $4 \mathrm{~h}$ pre-feeding (a.m. sampling) and $4 \mathrm{~h}$ post-feeding (p.m. sampling) on day 21-28. Fecal samples were transferred to aluminum pans and held at $60{ }^{\circ} \mathrm{C}$ in a forced-air oven until completely dry. Fecal samples were then ground to pass a 1-mm Wiley mill screen, and a single composite was prepared for each cow by mixing equal DM from both samples. Fecal samples were analyzed for DM, OM, ash-free NDFom, ash-free ADFom and total N. Acid detergent insoluble ash (AIA) content of feed and feces was used as an internal marker to determine apparent total tract nutrient digestibility coefficients. At the times of fecal sampling, spot urine samples were obtained from all cows by stimulation of the vulva. After collection, $15 \mathrm{ml}$ of urine was pipetted into specimen containers holding $60 \mathrm{ml}$ of $0.072 \mathrm{NH}_{2} \mathrm{SO}_{4}$ and stored at $-20^{\circ} \mathrm{C}$ until analysis.

\subsection{Ruminal fermentation characteristics}

On each period, rumen fluid was sampled at 09:30 h using a stomach tube. The initial $100 \mathrm{ml}$ of the aspirated fluid was discarded to minimize salivary contamination. The $\mathrm{pH}$ of the second portion was measured immediately using a mobile pH meter (WTW Multilab 540 Ionalyzer, $\mathrm{pH} / \mathrm{mV}$ Meter, Weilheim, Germany), and $5 \mathrm{ml}$ of the filtrate was mixed with $1 \mathrm{ml}$ of $25 \% \mathrm{HPO}_{3}$ (wt/vol) for VFA analysis. A sub-sample of $5 \mathrm{ml}$ was combined with $1 \mathrm{ml}$ of $0.2 \mathrm{~N} \mathrm{HCl}$ for $\mathrm{NH}_{3}-\mathrm{N}$ analysis. Sub-samples were frozen at $-20{ }^{\circ} \mathrm{C}$ until analysis (Broderick and Kang, 1980).

\subsection{Enumeration of rumen protozoa}

Rumen ciliates were identified according to the method of Dehority (2003). Two ml of rumen fluid was pipetted into a screw-capped test tube containing $5 \mathrm{ml}$ of formalinized physiological saline (containing $20 \mathrm{ml}$ formaldehyde in $100 \mathrm{ml}$ saline which contained $0.85 \mathrm{~g}$ sodium chloride in $100 \mathrm{ml}$ distilled water). Thereafter, two drops of brilliant green dye $(2 \mathrm{~g}$ brilliant green and $2 \mathrm{ml}$ glacial acetic diluted to $100 \mathrm{ml}$ with distilled water) were added to the test tube, mixed thoroughly and allowed to stand overnight at room temperature. Total and differential counts of protozoa were made in 30 microscopic fields at a magnification of $20 \times$ in a Haemocytometer (Neubauerimproved, Marienfeld, Germany).

\subsection{Milk production and milk composition}

Cows were milked 3 times daily (0500 h, $1300 \mathrm{~h}$ and $2100 \mathrm{~h}$ ) and the amount of milk produced for each cow at each milking was recorded using special graduated jars (Agri\& SD Co., Frankfurt, Germany). Before each milking, cows were monitored for udder inflammation and presence of milk clots in the teats to ensure that milk yield and composition were not affected by mastitis. During the last week of each 28-d period, milk samples were taken from each cow at each milking and stored at $4{ }^{\circ} \mathrm{C}$ with a preservative (2-bromo-2-nitropropan-1,3-diol) until analyzed for fat, protein, and lactose.

\subsection{Analytical methods}

Dry matter content was determined by oven drying at $105{ }^{\circ} \mathrm{C}$ for $48 \mathrm{~h}$ (AOAC, 1990; method 930.15). Ash content was determined by incineration at $550{ }^{\circ} \mathrm{C}$ overnight, and the OM content was calculated as the difference between 100 and the percentage of ash (AOAC, 1990; method 942.05). The NDFom was determined, with sodium sulfite in ND, according to Van Soest et al. (1991), and ADFom was determined according to AOAC (1990; method 973.18) and expressed exclusive of residual ash. Lignin was determined by solubilization of cellulose with sulfuric acid (Robertson and Van Soest, 1981). Nitrogen content in feed, feces and urine was determined by the Kjeldahl method (AOAC, 1990; method 954.01). The AIA was measured by Van Keulen and Young (1977).

Daily urine volume and excretion of allantoin, uric acid, and total purine derivatives (PD) were estimated from urinary creatinine concentration and BW (Valadares et al., 1999). After thawing at room temperature, the urine sample was filtered through Whatman No. 1 filter paper; the filtrate was analyzed for creatinine. The mean daily creatinine excretion rate $(29.0 \mathrm{mg} / \mathrm{kg}$ of BW per day) was computed using the data from all cows in the trial. Urine volume was used to compute daily excretion of urea, and allantoin, and uric acid from spot urine samples were estimated: BW $\times 29$ / creatinine concentration (mg/L) (Valadares et al., 1999). Total purine derivative (PD) excretion was the sum of allantoin and uric acid excreted in urine plus allantoin and uric acid excreted in milk (Chen and Gomes, 1995). Urinary purine derivatives were estimated by spectrophotometric method (Chen and Gomes, 1995). Briefly, allantoin was determined in urine by colorimetric method after conversion of allantoin to phenyl hydrazone at $522 \mathrm{~nm}$. Uric acid was measured from the reduction in O.D. at $293 \mathrm{~nm}$ following conversion of uric acid to allantoin with uricase. The urinary PD excreted in a day was used in the iteration process to calculate the microbial protein supply as described (Chen and Gomes, 1995) which is given below:

$Y=0.85 X+\left(0.150 W^{0.75}\right)$

where $Y$ is the urinary PD excretion as mmol/day, $X$ is the absorbed exogenous purine as mmol/day, and $W$ is the live weight.

Based on equations the amount of exogenous purines absorbed can then be estimated from the daily excretion of PD.

$X=\left(Y-0.385 \times W^{0.75}\right) / 0.85$

Ruminal synthesis of microbial $\mathrm{N}$ was computed as

Microbial N $(\mathrm{gN} / d)=\frac{X(\mathrm{~m} / \mathrm{mold}) \times 70}{0.116 \times 0.83 \times 1000}=0.727 X$

where 70 is the $\mathrm{N}$ content of purines ( $\mathrm{mg} \mathrm{N} / \mathrm{mmol}$ ), 0.116 is the mean ratio of purine- $\mathrm{N}$ : total- $\mathrm{N}$ measured for mixed rumen microbes in the present study and 0.83is the assumed digestibility of microbial purines (Chen and Gomes, 1995). 
Table 2

Secondary metabolites levels ( $\mathrm{g} / \mathrm{kg}$ DM diet) of PPE.

\begin{tabular}{|c|c|c|c|c|c|}
\hline \multirow[t]{2}{*}{ Secondary compounds ( $\mathrm{g} / \mathrm{kg}$ diet) } & \multirow[t]{2}{*}{$\mathrm{mg} / \mathrm{ml}$ extract } & \multicolumn{4}{|c|}{ Treatment $^{\mathrm{a}}$} \\
\hline & & PPEO & PPE400 & PPE800 & PPE1200 \\
\hline Total phenolics & 65 & 3.50 & 4.56 & 5.58 & 6.6 \\
\hline Total tannins & 56 & 1.00 & 1.92 & 2.80 & 3.66 \\
\hline Condensed tannins & 0.08 & - & 0.0014 & 0.0026 & 0.0038 \\
\hline Hydrolyzable tannins & 6.3 & - & 0.11 & 0.22 & 0.33 \\
\hline Saponins & 35.5 & 11.40 & 11.98 & 12.54 & 13.09 \\
\hline Aqueous fraction ${ }^{\mathrm{b}}$ & 227.9 & - & 3.73 & 7.30 & 10.85 \\
\hline Dihydromaltol & 0.005 & - & 0.00008 & 0.00016 & 0.00024 \\
\hline Butanoic acid, 3-methyl-hexyl ester & 0.002 & - & 0.00084 & 0.00168 & 0.00252 \\
\hline Thymol & 0.003 & - & 0.00004 & 0.00009 & 0.00013 \\
\hline
\end{tabular}

a Treatment: PPE0 =control, no additive; PPE $400=400 \mathrm{ml}$ pomegranate peel extract $/ \mathrm{cow} / \mathrm{d} ; \mathrm{PPE} 800=800 \mathrm{ml}$ pomegranate peel extract $/ \mathrm{cow} / \mathrm{d}$; PPE $1200=1200 \mathrm{ml}$ pomegranate peel extract/cow/d.

${ }^{\mathrm{b}}$ Aqueous fraction (lectins, polypeptides, starch) (Cowan, 1999).

Total phenolics (TP) were measured using the FolinCiocalteau method (Makkar, 2000). Extract (200 mg) dissolved in acetone:water $(10 \mathrm{ml} ; 70: 30, \mathrm{v} / \mathrm{v})$ in an ultrasonic bath for $20 \mathrm{~min}$. The contents were centrifuged $\left(4^{\circ} \mathrm{C}\right.$, $10 \mathrm{~min}, 3000 \mathrm{~g}$ ) and the supernatant was kept on ice until analysis. Non-tannin phenolics (NTP) were determined using absorption to insoluble polyvinylpyrrolidone. The insoluble polyvinylpyrrolidone (100 $\mathrm{mg}$ ) was weighed into $100 \mathrm{~mm} \times 12 \mathrm{~mm}$ test tubes. Distilled water, $1 \mathrm{ml}$, and then $1 \mathrm{ml}$ tannin containing extract were added and vortexed. The tube was kept at $4{ }^{\circ} \mathrm{C}$ for $15 \mathrm{~min}$, vortexed again, and centrifuged (3000g) for $10 \mathrm{~min}$ and the supernatant collected. Phenolic content in the supernatant was measured by the Folin-Ciocalteau reaction and this was accepted as the NTP (Makkar, 2000).Total tannins (TT) were calculated as the difference between TP and NTP. Tannic acid (Merck GmbH, Darmstadt, Germany) was used as the standard to express the amount of TP and TT. Condensed tannins (CT) were measured by the $\mathrm{HCl}-$ butanol method (Makkar, 2000). An aliquot from the above acetone:water extract $(0.5 \mathrm{ml}$; although this extract occasionally needed diluting with the extractant, acetone: water, if final absorbance at $550 \mathrm{~nm}$ exceeded 0.6 absorbance units) plus $\mathrm{HCl}$-butanol $(3 \mathrm{ml}$ ) and ferric ammonium sulfate $(0.1 \mathrm{ml})$ reagents were heated in a boiling water bath for $60 \mathrm{~min}$. Absorbance was read at $550 \mathrm{~nm}$. Hydrolyzable tannins were analyzed using Rhodanine assay according to Makkar (2000). The results were expressed as gallotannin.

Ten milliliters of the extract were prepared after TP separation; a double volume of n-butanol was added to fractionate saponins (Makkar et al., 1998). The remaining solution was considered to be the aqueous fraction (AF) containing other secondary compounds such lectins, polypeptides and starch (Cowan, 1999). Dihydromaltol, butanoic acid, 3-methyl-hexyl ester and thymol were measured by gas chromatography/mass spectrometry (GC/MS).

\subsection{Statistical analysis}

Data were analyzed as a $4 \times 4$ Latin square, simple changeover, design using the MIXED procedure (SAS, 2002). The model included the treatments and periods as the fixed effects and cow as a random effect. The contrast statement was used to determine the linear and quadratic cow response to increasing levels of the extract in the diet. Differences between treatments were declared significant at $P \leq 0.05$ using the Tukey correction for multiple comparisons, and trends were discussed at $P \leq 0.10$ unless otherwise stated.

$Y_{i j k}=\mu+T_{i}+P_{j}+A_{k}+e_{i j k}$

where $Y_{i j k}$ is a dependent variable, $\mu$ is the overall mean, $T_{i}$ is the fixed effect of dose $(j=1-4), P_{l}$ is the fixed effect of period $(l=1-4)$ nested within square, $A_{k}$ is the random effect of cow nested within square and $e_{i j k}$ is the residual.

In the present experiment, power of test was applied and results were added to the tables. Power of test is defined as the probability of concluding a mean difference when such a difference truly exists (Tempelman, 2004).

\section{Results}

\subsection{Nutrient digestibility, feed intake and body weight}

Ingredients and chemical composition of the basic TMR fed to cows are given in Table 1 . There were no significant effects of the extract on total-tract apparent digestibility of nutrients, DMI and body weight (Table 3 ).

\subsection{Ruminal fermentation characteristics}

Ruminal pH, concentration of total VFA, and molar proportions of individual VFA were not affected by the addition of PPE in the diet (Table 4). However, feeding PPE decreased $\mathrm{NH}_{3}-\mathrm{N}$ concentration $(Q=0.031)$ (Fig. 1).

\subsection{Enumeration of rumen protozoa}

Total number of protozoa, genus Isotricha and Entodinium (Figs. 2-4) in cows offered PPE diet was lower than in those fed the control diet without PPE, but populations of Dasytricha, Diplodinium, Eudiplodinium, Stracodinium, 
Table 3

Total-tract digestibility, nutrient intake and BW change in lactating cows fed PPE-supplemented diets.

\begin{tabular}{|c|c|c|c|c|c|c|c|c|}
\hline \multirow[t]{2}{*}{ Treatment $^{\mathrm{a}}$} & \multicolumn{5}{|c|}{ Digestibility (\%) } & \multirow[t]{2}{*}{ DMI (kg/d) } & \multirow[t]{2}{*}{ DMI (kg/w $\left.\mathrm{w}^{0.75}\right)$} & \multirow[t]{2}{*}{ BW change $(\mathrm{kg})$} \\
\hline & DM & OM & $\mathrm{CP}$ & NDF & $\mathrm{ADF}$ & & & \\
\hline PPE0 & 64.94 & 67.05 & 69.40 & 55.91 & 47.92 & 26.16 & 4.20 & 8.50 \\
\hline PPE400 & 66.29 & 68.56 & 69.58 & 56.86 & 52.62 & 24.44 & 3.84 & 13.00 \\
\hline PPE800 & 68.24 & 67.74 & 68.67 & 59.29 & 49.70 & 23.80 & 3.77 & 13.25 \\
\hline PPE1200 & 65.34 & 67.47 & 68.65 & 56.55 & 49.35 & 25.25 & 4.03 & 0.00 \\
\hline $\mathrm{SEM}^{\mathrm{b}}$ & 2.324 & 1.155 & 1.955 & 2.675 & 1.451 & 0.742 & 0.135 & 6.166 \\
\hline \multicolumn{9}{|l|}{$P$-value } \\
\hline Linear & 0.771 & 0.931 & 0.730 & 0.728 & 0.840 & 0.667 & 0.667 & 0.395 \\
\hline Quadratic & 0.369 & 0.471 & 0.963 & 0.516 & 0.132 & 0.391 & 0.271 & 0.200 \\
\hline \multicolumn{9}{|l|}{ Power of tests } \\
\hline PPE0 vs. PPE400 & 0.071 & 0.175 & 0.153 & 0.162 & 0.148 & 0.425 & 0.220 & 0.110 \\
\hline PPE0 vs. PPE800 & 0.129 & 0.162 & 0.166 & 0.121 & 0.180 & 0.508 & 0.384 & 0.139 \\
\hline PPE0 vs. PPE1200 & 0.056 & 0.057 & 0.064 & 0.590 & 0.075 & 0.293 & 0.109 & 0.454 \\
\hline PPE400 vs. PPE800 & 0.090 & 0.068 & 0.084 & 0.101 & 0.122 & 0.102 & 0.098 & 0.052 \\
\hline PPE400 vs. PPE1200 & 0.069 & 0.074 & 0.075 & 0.054 & 0.153 & 0.160 & 0.150 & 0.406 \\
\hline PPE800 vs. PPE1200 & 0.126 & 0.056 & 0.050 & 0.133 & 0.058 & 0.254 & 0.362 & 0.652 \\
\hline
\end{tabular}

a Treatment: PPE0=control, no additive; PPE $400=400 \mathrm{ml}$ pomegranate peel extract $/$ cow $/ \mathrm{d} ;$ PPE $800=800 \mathrm{ml}$ pomegranate peel extract $/$ cow $/ \mathrm{d}$ PPE1200 = $1200 \mathrm{ml}$ pomegranate peel extract/cow/d.

b $\mathrm{SEM}=$ Standard error of the mean.

Table 4

Ruminal pH, $\mathrm{NH}_{3}-\mathrm{N}(\mathrm{mg} / \mathrm{L})$, total VFA (mmol) and individual VFA (mol/100 mol) in lactating dairy cows fed PPE-supplemented diets.

\begin{tabular}{|c|c|c|c|c|c|c|c|c|c|}
\hline \multirow[t]{2}{*}{ Treatment $^{1}$} & \multicolumn{9}{|c|}{ Parameters } \\
\hline & $\mathrm{pH}$ & $\mathrm{NH}_{3}-\mathrm{N}$ & TVFA & Ac & $\operatorname{Pr}$ & $\mathrm{Bu}$ & IVal & Val & Ac:Pr \\
\hline PPE0 & 6.55 & $171.06^{\mathrm{a}}$ & 109.71 & 46.15 & 22.49 & 21.70 & 2.76 & 3.28 & 2.05 \\
\hline PPE400 & 6.60 & $93.66^{\mathrm{b}, \mathrm{c}}$ & 105.74 & 45.82 & 22.43 & 22.90 & 2.91 & 3.22 & 2.06 \\
\hline PPE800 & 6.65 & $87.31^{\mathrm{C}}$ & 108.09 & 44.66 & 22.30 & 24.31 & 3.32 & 2.80 & 2.00 \\
\hline PPE1200 & 6.63 & $143.45^{\mathrm{a}, \mathrm{b}}$ & 101.50 & 46.03 & 21.28 & 24.86 & 3.23 & 3.14 & 2.18 \\
\hline SEM $^{2}$ & 0.100 & 23.34 & 9.021 & 0.643 & 0.773 & 1.138 & 0.169 & 0.130 & 0.071 \\
\hline \multicolumn{10}{|l|}{$P$-value } \\
\hline Linear & 0.567 & 0.434 & 0.600 & 0.616 & 0.319 & 0.077 & 0.055 & 0.189 & 0.358 \\
\hline Quadratic & 0.766 & 0.031 & 0.890 & 0.233 & 0.553 & 0.784 & 0.510 & 0.176 & 0.299 \\
\hline \multicolumn{10}{|l|}{ Power of tests } \\
\hline PPE0 vs. PPE400 & 0.065 & 0.328 & 0.166 & 0.066 & 0.054 & 0.119 & 0.105 & 0.088 & 0.051 \\
\hline PPE0 vs. PPE800 & 0.085 & 0.667 & 0.257 & 0.148 & 0.275 & 0.280 & 0.307 & 0.446 & 0.082 \\
\hline PPE0 vs. PPE1200 & 0.095 & 0.109 & 0.100 & 0.056 & 0.322 & 0.375 & 0.291 & 0.122 & 0.182 \\
\hline PPE400 vs. PPE800 & 0.063 & 0.174 & 0.160 & 0.056 & 0.060 & 0.155 & 0.209 & 0.323 & 0.079 \\
\hline PPE400 vs. PPE1200 & 0.061 & 0.266 & 0.178 & 0.056 & 0.181 & 0.273 & 0.161 & 0.080 & 0.158 \\
\hline PPE800 vs. PPE1200 & 0.056 & 0.774 & 0.097 & 0.057 & 0.205 & 0.273 & 0.068 & 0.202 & 0.219 \\
\hline
\end{tabular}

${ }^{1}$ Treatment: PPE0 $=$ control, no additive; PPE400 $=400 \mathrm{ml}$ pomegranate peel extract $/$ cow $/ \mathrm{d} ;$ PPE $800=800 \mathrm{ml}$ pomegranate peel extract $/$ cow $/ \mathrm{d}$; PPE1200 = 1200 ml pomegranate peel extract/cow/d. Ac: acetate; Pr: propionate; Bu: butyrate; IVal: isovalerate; Val: valerate; Ac:Pr: acetate propionate ratio.

${ }^{2} \mathrm{SEM}=$ Standard error of the mean.

a,b,c Means within a column with different superscripts differ $(\mathrm{P}<0.05)$ using t-test for pairwise comparison.

Polyplastron and Ophryoscolex were not influenced by PPE (Table 5).

\subsection{Purine derivatives and microbial $N$}

Allantoin contents in urine and milk were increased $(Q=0.007)$ as the level of PPE in the diet increased (Table 6). However, PPE did not alter the uric acid contents in urine and milk. Microbial $\mathrm{N}(\mathrm{g} / \mathrm{d})$ was increased in cows receiving the PPE800 diet $(Q=0.013)$. The power test value of microbial N for PPE0 and PPE800 treatments was 0.532 and most likely, there are significant differences between the treatments.

\subsection{Milk production and milk composition}

Milk and 4\% FCM yields were higher in PPE800 compared to control cows (Tables 7 and $8, Q=0.042$ ). The power test value of milk production for PPE0 and PPE800 treatments was 0.562 and most likely, there are significant differences between the treatments. Concentrations of milk fat, true protein, and lactose were not affected by PPE supplementation. Milk fat and protein yields $(\mathrm{kg} / \mathrm{d})$ were increased by PPE800 supplementation. The power test value of milk production for PPE0 and PPE800 treatments was 0.562 and most likely, there are significant differences between the treatments. The milk efficiency 


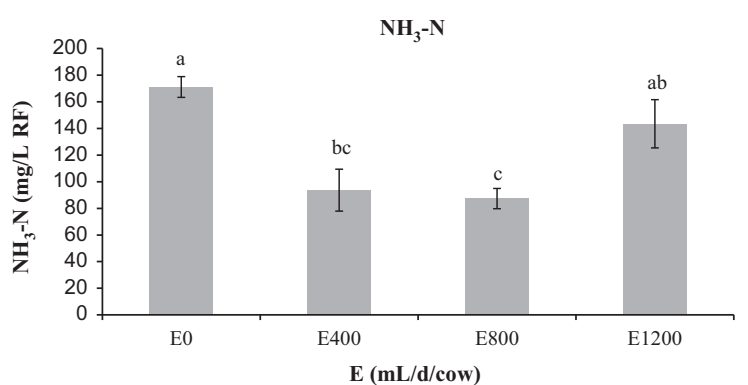

Fig. 1. Effect of PPE (ml/d/cow) on ruminal $\mathrm{NH}_{3}-\mathrm{N}$ concentration in dairy cows. Whiskers represent SE and $(\mathrm{a}-\mathrm{c})$ indicate significant differences among experimental diets $(P<0.05)$.

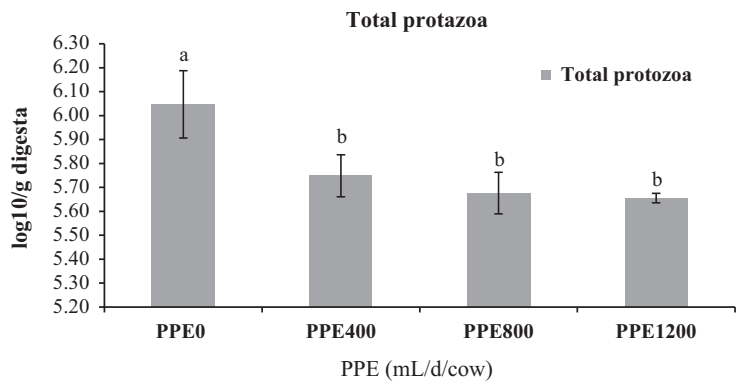

Fig. 2. Effect of PPE (ml/d/cow) on ruminal total protozoa in dairy cows. Whiskers represent SE and $(\mathrm{a}-\mathrm{c})$ indicate significant differences among experimental diets $(P<0.05)$.

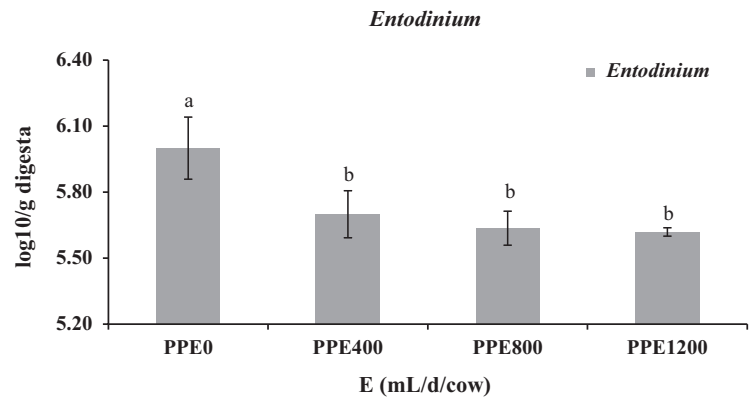

Fig. 3. Effect of PPE $(\mathrm{ml} / \mathrm{d} / \mathrm{cow})$ on ruminal Entodinium population in dairy cows. Whiskers represent SE and $(\mathrm{a}-\mathrm{c})$ indicate significant differences among experimental diets $(P<0.05)$.

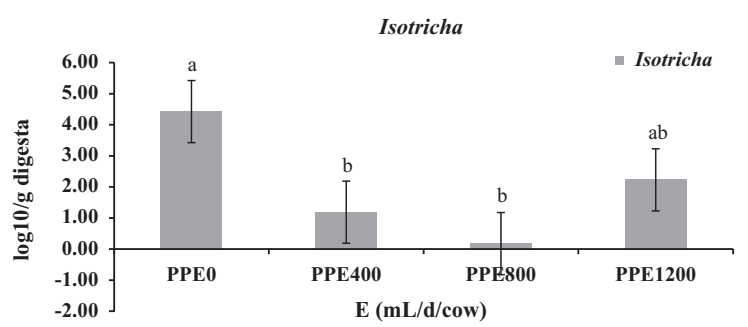

Fig. 4. Effect of PPE $(\mathrm{ml} / \mathrm{d} / \mathrm{cow})$ on ruminal Isotricha populations in dairy cows. Whiskers represent SE and $(\mathrm{a}-\mathrm{c})$ indicate significant differences among experimental diets $(P<0.05)$.

( $\mathrm{kg}$ of milk yield $/ \mathrm{kg}$ of DMI) was significantly $(Q=0.035)$ higher for cows fed the PPE800 than those fed the PPE0 diets.

\section{Discussion}

\subsection{Nutrient digestibility, feed intake and body weight}

Apparent total-tract digestibilities of nutrients were not affected by PPE supplementation, which can be explained by the optimum ruminal $\mathrm{pH}$ values (Table 4 ) in all treatments (Van Soest, 1994). Similar to our result, Dschaak et al. (2011) observed no effects on digestibility of DM, $\mathrm{OM}, \mathrm{CP}$, and ADFom with the addition of quebracho condensed tannin extract at 3\% of DM. In contrast, Jami et al. (2012) showed that using $1-4 \%$ pomegranate peel extract improved DM, CP, and NDFom digestibility in dairy cows. However, high concentrations of hydrolyzable tannins might reduce the digestibility of nutrients particularly proteins(Abarghuei et al., 2010; Reed, 1995). These results indicate that the effects of secondary metabolites on nutrients digestibility vary with the concentration of these metabolites, chemical structure and with the source of the plant used (Abarghuei et al., 2010). Van Soest (1994) illustrated that in general there is a positive correlation between voluntary intake and in vivo digestibility. In the present study, DMI was not influenced by inclusion of PPE in the diets which was probably due to lack of differences in nutrient digestibility. The effects of secondary metabolites on feed intake in ruminants have been inconsistent among studies (i.e., either had no effect (Benchaar et al., 2008), increase (Jami et al., 2012) or decrease (Abarghuei et al., 2011; Reed, 1995)). Vitti et al. (2005) reported that it was not possible to predict the beneficial or harmful nutritional effects of the secondary metabolite per se. Addition of PPE had no effect on BW change which indicated that the energy for milk production had been met by the energy in the diets (NRC, 2001). These results are consistent with the findings of Shabtay et al. (2012) who added $10-40 \mathrm{~g} / \mathrm{kg}$ DM of concentrated pomegranate extract to the rations of lactating cows. In contrast, Shabtay et al. (2008) demonstrated that dietary supplementation with fresh pomegranate peels tended to increase BW gain in bull calves.

\subsection{Ruminal fermentation characteristics}

Ruminal pH values varied from 6.55 to 6.65 (Table 4), which were within the optimum ranges $(6.7 \pm 0.5)$ for maintaining normal cellulolytic organism (Van Soest, 1994). The effects of secondary metabolites on ruminal $\mathrm{pH}$ have been variable among studies; either no effect (Dschaak et al., 2011) or increase (Jami et al., 2012) being reported. Ruminal $\mathrm{NH}_{3}-\mathrm{N}$ concentration in the experimental diets was within the optimum range $(87.31-171.06 \mathrm{mg} / \mathrm{l})$ (Fig. 1). Reduced ruminal $\mathrm{NH}_{3}-\mathrm{N}$ concentrations are typical when protozoa are inhibited (Williams and Coleman, 1991), presumably as a result of depressed bacterial lysis (Hristov et al., 1999). Belanche et al. (2012) noted that the protozoa of Entodinium sp. were responsible for most ruminal bacterial breakdown. In the current work, suppressing Entodinium by PPE addition (Table 5) may have led to the decrease ruminal $\mathrm{NH}_{3}-\mathrm{N}$ concentration. Also, concentration of $\mathrm{NH}_{3}-\mathrm{N}$ in the ruminal fluid is influenced by ammonia uptake by ruminal microorganisms (Agle et al., 2010), suggesting that another 
Table 5

Effects of PPE on ruminalprotozoal concentration ( $\log _{10} / \mathrm{g}$ digesta).

\begin{tabular}{|c|c|c|c|c|c|c|c|c|c|}
\hline \multirow[t]{2}{*}{ Treatment $^{1}$} & \multicolumn{9}{|c|}{ Protozoa } \\
\hline & Total & Entodinium & Isotricha & Dasytricha & Diplodinium & Eudiplodinium & Stracodinium & Polyplastron & Ophryoscolex \\
\hline PPE0 & $6.05^{\mathrm{a}}$ & $6.00^{\mathrm{a}}$ & $4.42^{\mathrm{a}}$ & 4.46 & 2.41 & 1.13 & 1.19 & 0.18 & 3.52 \\
\hline PPE400 & $5.75^{\mathrm{b}}$ & $5.70^{\mathrm{b}}$ & $1.19^{\mathrm{b}}$ & 4.38 & 2.17 & 0.18 & 0.18 & 1.19 & 1.19 \\
\hline PPE800 & $5.68^{\mathrm{b}}$ & $5.64^{\mathrm{b}}$ & $0.18^{\mathrm{b}}$ & 4.36 & 2.21 & 0.18 & 0.18 & 1.10 & 2.05 \\
\hline PPE1200 & $5.65^{\mathrm{b}}$ & $5.62^{\mathrm{b}}$ & $2.23^{\mathrm{a}, \mathrm{b}}$ & 4.38 & 2.05 & 0.18 & 0.18 & 0.18 & 2.14 \\
\hline SEM $^{2}$ & 0.033 & 0.035 & 0.765 & 0.130 & 1.114 & 0.478 & 0.506 & 0.789 & 0.833 \\
\hline \multicolumn{10}{|l|}{$P$-value } \\
\hline Linear & 0.0002 & 0.0003 & 0.068 & 0.725 & 0.992 & 0.228 & 0.228 & 0.980 & 0.410 \\
\hline Quadratic & 0.0057 & 0.0068 & 0.014 & 0.374 & 0.697 & 0.356 & 0.355 & 0.267 & 0.196 \\
\hline \multicolumn{10}{|l|}{ Power of tests } \\
\hline PPE0 vs. PPE400 & 0.481 & 0.444 & 0.876 & 0.102 & 0.064 & 0.225 & 0.225 & 0.225 & 0.391 \\
\hline PPE0 vs. PPE800 & 0.633 & 0.639 & 1.000 & 0.123 & 0.112 & 0.225 & 0.225 & 0.225 & 0.210 \\
\hline PPE0 vs. PPE1200 & 0.785 & 0.763 & 0.495 & 0.196 & 0.073 & 0.225 & 0.225 & 0.000 & 0.192 \\
\hline PPE400 vs. PPE800 & 0.147 & 0.112 & 0.225 & 0.064 & 0.149 & 0.000 & 0.000 & 0.156 & 0.130 \\
\hline PPE400 vs. PPE1200 & 0.267 & 0.162 & 0.146 & 0.145 & 0.057 & 0.000 & 0.000 & 0.225 & 0.138 \\
\hline PPE800 vs. PPE1200 & 0.076 & 0.073 & 0.453 & 0.164 & 0.170 & 0.000 & 0.000 & 0.148 & 0.055 \\
\hline
\end{tabular}

a,b Means within a row with different superscripts differ $(P<0.05)$ using $t$-test for pairwise comparison

${ }^{1}$ Treatment: PPE0 $=$ control, no additive; PPE $400=400 \mathrm{ml}$ pomegranate peel extract $/ \mathrm{cow} / \mathrm{d} ; \mathrm{PPE} 800=800 \mathrm{ml}$ pomegranate peel extract $/ \mathrm{cow} / \mathrm{d}$; PPE1200 $=1200 \mathrm{ml}$ pomegranate peel extract/cow $/ \mathrm{d}$.

${ }^{2} \mathrm{SEM}=$ Standard error of the mean.

Table 6

Purine derivates concentration in the urine and milk and microbial $\mathrm{N}$ in dairy cows fed PPE.

\begin{tabular}{|c|c|c|c|c|c|c|c|c|}
\hline \multirow[t]{2}{*}{ Treatment $^{1}$} & \multicolumn{3}{|l|}{ Urine } & \multicolumn{3}{|l|}{ Milk } & \multirow[t]{2}{*}{ TPD } & \multirow[t]{2}{*}{ MN } \\
\hline & A & UA & $\mathrm{A}+\mathrm{UA}$ & A & UA & $A+U A$ & & \\
\hline PPE0 & $281.65^{\mathrm{b}, \mathrm{c}}$ & 22.23 & $303.88^{b}$ & $14.08^{\mathrm{b}, \mathrm{c}}$ & 1.11 & $15.19^{\mathrm{b}}$ & $319.08^{b}$ & $231.45^{\mathrm{b}}$ \\
\hline PPE400 & $388.27^{a, b}$ & 27.39 & $415.66^{\mathrm{a}, \mathrm{b}}$ & $19.41^{a, b}$ & 1.37 & $20.78^{a, b}$ & $436.45^{\mathrm{a}, \mathrm{b}}$ & $331.52^{\mathrm{a}, \mathrm{b}}$ \\
\hline PPE800 & $438.48^{\mathrm{a}}$ & 47.38 & $485.86^{\mathrm{a}}$ & $21.92^{\mathrm{a}}$ & 2.37 & $24.29^{\mathrm{a}}$ & $510.15^{a}$ & $394.95^{a}$ \\
\hline PPE1200 & $214.12^{\mathrm{c}}$ & 32.40 & $246.52^{\mathrm{b}}$ & $10.71^{\mathrm{c}}$ & 1.62 & $12.33^{\mathrm{b}}$ & $258.84^{\mathrm{b}}$ & $180.03^{b}$ \\
\hline SEM $^{2}$ & 41.491 & 10.663 & 50.598 & 2.094 & 0.553 & 2.530 & 53.128 & 45.445 \\
\hline \multicolumn{9}{|l|}{$P$-value } \\
\hline Linear & 0.447 & 0.330 & 0.668 & 0.447 & 0.330 & 0.668 & 0.668 & 0.671 \\
\hline Quadratic & 0.007 & 0.381 & 0.013 & 0.007 & 0.381 & 0.013 & 0.013 & 0.013 \\
\hline \multicolumn{9}{|l|}{ Power of tests } \\
\hline PPE0 vs. PPE400 & 0.637 & 0.132 & 0.661 & 0.599 & 0.133 & 0.662 & 0.662 & 0.666 \\
\hline PPE0 vs. PPE800 & 0.493 & 0.570 & 0.521 & 0.493 & 0.569 & 0.521 & 0.521 & 0.532 \\
\hline PPE0 vs. PPE1200 & 0.180 & 0.116 & 0.150 & 0.179 & 0.117 & 0.129 & 0.129 & 0.130 \\
\hline PPE400 vs. PPE800 & 0.146 & 0.339 & 0.176 & 0.145 & 0.339 & 0.176 & 0.176 & 0.180 \\
\hline PPE400 vs. PPE1200 & 0.682 & 0.075 & 0.491 & 0.681 & 0.075 & 0.430 & 0.491 & 0.492 \\
\hline PPE800 vs. PPE1200 & 0.620 & 0.142 & 0.528 & 0.620 & 0.143 & 0.490 & 0.528 & 0.535 \\
\hline
\end{tabular}

${ }^{\mathrm{a}-\mathrm{c}}$ Means within a row with different superscripts differ $(P<0.05)$ using $t$-test for pairwise comparison.

${ }^{1}$ Treatment: $\mathrm{PPE} 0=$ control, no additive; PPE400 $=400 \mathrm{ml}$ pomegranate peel extract $/ \mathrm{cow} / \mathrm{d} ; \mathrm{PPE} 800=800 \mathrm{ml}$ pomegranate peel extract $/$ cow $/ \mathrm{d}$; PPE1200=1200 ml pomegranate peel extract/cow/d; A: Allantoin (mmol/d), UA: uric acid (mmol/d), A+UA: allantoin+uric acid (mmol/d), TPD: total purine derivates, $\mathrm{MN}$ : microbial $\mathrm{N}(\mathrm{g} / \mathrm{d})$.

${ }^{2} \mathrm{SEM}=$ Standard error of the mean.

explanation for the reduced $\mathrm{NH}_{3}-\mathrm{N}$ concentration is an overall increase in microbial protein synthesis (Table 6). However, at the highest inclusion of PPE (PPE1200), the antimicrobial activity of PSM could be attributed to the decrease in microbial protein production.

As VFAs are the end products of rumen microbial fermentation, and represent the main supply of energy for the ruminant (Van Soest, 1994), a reduction in their production would be nutritionally unfavorable for the animal. The addition of PPE had no effect on total and individual VFAs and acetate to propionate ratio, which is probably due to the lack of significant effect on DMI (Boudon et al., 2007).Effects of secondary metabolites on total VFA concentration and VFA pattern, however, have been variable among studies, depending on the dosage and the source of component (Benchaar et al., 2008).

\subsection{Enumeration of rumen protozoa}

Concentration of Isotricha protozoa was decreased by more than $50 \%$ by PPE supplementation (Fig. 4) whereas Eudiplodinium, Stracodinium and Polyplastron were completely vanished. The antiprotozoal effect of PPE was most likely due to the phenolic structure of active compounds (i.e., saponins). This structure may disrupt the protozoal membrane, inactivation of protozoal enzymes, 
and deprive of substrates and metal ions which are essential for cell metabolism (Calsamiglia et al., 2007; Goel et al., 2005). Research on the influence of PSM on ruminal protozoa population were not consistent (i.e., either no effect (Benchaar et al., 2008), decreases (Hess et al., 2004; Nasri and Ben Salem, 2012) or increases (Raghuvansi et al., 2007)). Such discrepancies may be due to the diet type, animal variability, sampling methods

Table 7

Milk production and milk efficiency of dairy cows fed PPE.

\begin{tabular}{|c|c|c|c|}
\hline Treatment $^{1}$ & $\begin{array}{l}\text { Milk production } \\
(\mathrm{kg} / \mathrm{d})\end{array}$ & $\begin{array}{l}4 \% \text { FCM } \\
(\mathrm{kg} / \mathrm{d})\end{array}$ & $\begin{array}{l}\text { Milk efficiency } \\
(\mathrm{kg} / \mathrm{kg})\end{array}$ \\
\hline PPE0 & $30.97^{\mathrm{b}}$ & $25.18^{b}$ & $1.187^{c}$ \\
\hline PPE400 & $33.30^{\mathrm{a}, \mathrm{b}}$ & $28.38^{\mathrm{a}, \mathrm{b}}$ & $1.372^{\mathrm{a}, \mathrm{b}}$ \\
\hline PPE800 & $34.20^{\mathrm{a}}$ & $29.94^{\mathrm{a}}$ & $1.383^{\mathrm{a}}$ \\
\hline PPE1200 & $31.78^{\mathrm{a}, \mathrm{b}}$ & $26.64^{\mathrm{a}, \mathrm{b}}$ & $1.255^{\mathrm{b}, \mathrm{c}}$ \\
\hline $\mathrm{SEM}^{2}$ & 0.923 & 1.343 & 0.058 \\
\hline \multicolumn{4}{|l|}{$P$-value } \\
\hline Linear & 0.451 & 0.360 & 0.435 \\
\hline Quadratic & 0.042 & 0.049 & 0.035 \\
\hline \multicolumn{4}{|l|}{ Power of tests } \\
\hline $\begin{array}{l}\text { PPE0 vs. } \\
\text { PPE400 }\end{array}$ & 0.446 & 0.545 & 0.489 \\
\hline $\begin{array}{l}\text { PPE0 vs. } \\
\text { PPE } 800\end{array}$ & 0.562 & 0.773 & 0.508 \\
\hline $\begin{array}{l}\text { PPE0 vs. } \\
\text { PPE1200 }\end{array}$ & 0.287 & 0.212 & 0.204 \\
\hline $\begin{array}{l}\text { PPE } 400 \text { vs. } \\
\text { PPE } 800\end{array}$ & 0.259 & 0.333 & 0.158 \\
\hline $\begin{array}{l}\text { PPE } 400 \text { vs. } \\
\text { PPE } 1200\end{array}$ & 0.255 & 0.240 & 0.274 \\
\hline $\begin{array}{l}\text { PPE } 800 \text { vs. } \\
\text { PPE } 1200\end{array}$ & 0.239 & 0.273 & 0.296 \\
\hline
\end{tabular}

${ }^{\mathrm{a}-\mathrm{c}}$ Means within a row with different superscripts differ $(P<0.05)$ using $t$-test for pairwise comparison.

${ }^{1}$ Treatment: $\mathrm{PPE} 0=$ control, no additive; PPE400 $=400 \mathrm{ml}$ pomegranate peel extract/cow/d; $P P E 800=800 \mathrm{ml}$ pomegranate peel extract /cow/d; PPE1200=1200 ml pomegranate peel extract/cow $/ \mathrm{d}$.

$2 \mathrm{SEM}=$ Standard error of the mean.
(Yanez Ruiz et al., 2004), level and type of plant metabolites (Patra and Saxena, 2011), and the variability in the adaptation of the protozoa to SPM, the previous experience of the animal to SPM, or both (Abreu et al., 2004; Wallace et al., 2002).

\subsection{Purine derivatives and microbial $N$}

Urinary purine derivative excretion was used to estimate ruminal microbial $\mathrm{N}$ (Chen and Gomes, 1995). In the present experiment, a significant effect of PPE addition (PPE400 and PPE800) on microbial N flow to the intestine was observed. A decreased concentration of rumen protozoa could increase the flow of microbial $\mathrm{N}$ to the intestine, benefiting the ruminant by increasing the amount of amino acids available for absorption (Williams and Coleman, 1991). Moreover, it has been illustrated that Entodinium sp. was responsible for most of ruminal bacterial breakdown (Belanche et al., 2012). In the current work, suppression of Entodinium by PPE (Table 5) may have led to improve the microbial $\mathrm{N}$ synthesis in the rumen. At the highest inclusion of PPE, however, the PSM content could be detrimental to the ruminal microorganism, thereby significantly decreasing microbial N synthesis.

\subsection{Milk production and milk composition}

Tannins in PPE have both adverse and beneficial effects in ruminants (Mueller-Harvey, 2006). High concentrations of hydrolyzable tannins could decrease feed intake, digestibility of $\mathrm{CP}$ and NDFom, and animal performance through their negative effects on palatability and digestion (Broderick et al., 1991; Reed, 1995). In the current study, however, PPE inclusion had no adverse effects on nutrient digestibility and intake, as also reflected in the higher milk and 4\% FCM yields and milk efficiency in cows fed PPE. Similarly, Jami et al. (2012) reported that using 4\% DM of pomegranate peel extract in dairy cows diet increased

Table 8

Milk composition and milk yield of dairy cows fed PPE.

\begin{tabular}{|c|c|c|c|c|c|c|}
\hline \multirow[t]{2}{*}{ Treatment $^{1}$} & \multicolumn{3}{|c|}{ Milk composition (\%) } & \multicolumn{3}{|c|}{ Milk yield (kg/d) } \\
\hline & Fat & Protein & Lactose & Fat & Protein & Lactose \\
\hline PPE0 & 3.27 & 3.12 & 4.74 & 1.00 & $0.96^{\mathrm{b}}$ & 1.46 \\
\hline PPE400 & 3. 41 & 3.22 & 4.68 & 1.13 & $1.07^{\mathrm{a}}$ & 1.56 \\
\hline PPE800 & 3.27 & 3.24 & 4.60 & 1.12 & $1.11^{\mathrm{a}}$ & 1.57 \\
\hline PPE1200 & 3.28 & 3.22 & 4.67 & 1.04 & $1.02^{\mathrm{a}, \mathrm{b}}$ & 1.49 \\
\hline SEM $^{2}$ & 0.087 & 0.084 & 0.081 & 0.030 & 0.027 & 0.047 \\
\hline \multicolumn{7}{|l|}{$P$-value } \\
\hline Linear & 0.826 & 0.421 & 0.425 & 0.439 & 0.119 & 0.709 \\
\hline Quadratic & 0.465 & 0.488 & 0.488 & 0.012 & 0.012 & 0.106 \\
\hline \multicolumn{7}{|l|}{ Power of tests } \\
\hline PPE0 vs. PPE400 & 0.128 & 0.109 & 0.106 & 0.853 & 0.380 & 0.329 \\
\hline PPE0 vs. PPE800 & 0.259 & 0.125 & 0.249 & 0.589 & 0.497 & 0.311 \\
\hline PPE0 vs. PPE1200 & 0.055 & 0.106 & 0.101 & 0.106 & 0.132 & 0.068 \\
\hline PPE400 vs. PPE800 & 0.527 & 0.177 & 0.175 & 0.107 & 0.158 & 0.172 \\
\hline PPE400 vs. PPE1200 & 0.141 & 0.050 & 0.054 & 0.229 & 0.128 & 0.127 \\
\hline PPE800 vs. PPE1200 & 0.066 & 0.071 & 0.125 & 0.161 & 0.211 & 0.142 \\
\hline
\end{tabular}

${ }^{\mathrm{a}, \mathrm{b}}$ Means within a row with different superscripts differ $(P<0.05)$ using $t$-test for pairwise comparison.

${ }^{1}$ Treatment: PPEO $=$ control, no additive; PPE $400=400 \mathrm{ml}$ pomegranate peel extract $/ \mathrm{cow} / \mathrm{d} ; \mathrm{PPE} 800=800 \mathrm{ml}$ pomegranate peel extract $/ \mathrm{cow} /$ d; PPE1200 $=1200 \mathrm{ml}$ pomegranate peel extract/cow $/ \mathrm{d}$.

${ }^{2} \mathrm{SEM}=$ Standard error of the mean. 
milk production. In contrast, in another study, milk and $4 \%$ FCM yields were not changed by Cinnamaldehyde, quebracho condensed tannin and Yucca schidigera saponin extracts (Benchaar et al., 2008). The increased daily milk protein yield in cows fed PPE (particularly PPE800) may be due to an increase in the flow of microbial protein (Table 6) to the intestine, benefiting the cows by increasing the amount of amino acids available for absorption (Makkar, 2003).

\section{Conclusions}

PPE had no influence on feed intake and the digestibility of DM, OM CP, NDFom and ADFom. Addition of PPE in the diet decreased ruminal $\mathrm{NH}_{3}$ concentration, total protozoal population, Entodinium sp., but increased microbial protein synthesis, milk and 4\% FCM yields and daily milk protein production. This study showed that water extraction can be uses as a simple and cheap procedure for extracting PPE, an alternative to commonly used expensive solvents. An inclusion level of $800 \mathrm{ml} \mathrm{PPE} / \mathrm{cow} / \mathrm{d}$ has a potential in manipulating the rumen fermentation and improving dairy cow performance. The commercial and industrial process for this extract is being done and the extract was concentrated and was standardized to ensure uniform and constant biological activity. Using of PPE in commercially on growing lamb and beef cattle is also being investigated.

\section{Conflicts of interest}

The authors wish to confirm that there are no known conflicts of interest associated with this publication and there has been no financial support for this work that could have influenced its outcome.

\section{Acknowledgment}

The authors would like to thank Iran National Science Foundation for the kind financial support for carrying out the trial, and gratefully acknowledge Dr. A. MokhtassiBidgoli for his help in statistical analysis and the generous assistance from Mr. Gary Easton for his English language correction of the manuscript.

\section{References}

AOAC, 1990. 15th ed.Official Methods of Analysis, vol. I. Association of Official Analytical Chemists, Arlington, VA, USA.

Abarghuei, M.J., Rouzbehan, Y., Alipour, D., 2010. The influence of the grape pomace on the ruminal parameters of sheep. Livest. Sci. 132 73-79.

Abarghuei, M.J., Rouzbehan, Y., Alipour, D., 2011. Effect of oak (Quercuslibani Oliv.) leave tannin on ruminal fermentation of sheep. J. Agric. Sci. Technol. 13, 1021-1032.

Abreu, A., Carulla, J.E., Lascano, C.E., Diaz, T.E., Kreuzer, M., Hess, H.D., 2004. Effects of Sapindus saponaria fruits on rumen fermentation and duodenal nitrogen flow of sheep fed a tropical grass diet with and without legume. J. Anim. Sci. 82, 1392-1400.

Adams, L.S., Seeram, N.P., Aggarwal, B.B., Takada, Y., Sand, D., Heber, D. 2006. Pomegranate juice, total pomegranate ellagitannins, and punicalagin suppress inflammatory cell signaling in colon cancer cells. J. Agric. Food Chem. 54, 980-985.
Agle, M., Hristov, A.N., Zaman, S., Schneider, C., Ndegwa, P., Vaddella, V.K. 2010. The effects of ruminally degraded protein on rumen fermentation and ammonia losses from manure in dairy cows. J. Dairy Sci. 93 $1625-1637$.

Alipour, D., Rouzbehan, Y., 2010. Effects of several levels of extracted tannin from grape pomace on intestinal digestibility of soybean meal. Livest. Sci. 128, 87-91.

Belanche, A., De La Fuente, G., Moorby, J.M., Newbold, C.J., 2012. Bacterial protein degradation by different rumen protozoal groups. J. Anim. Sci. 90, 4495-4504.

Benchaar, C., McAllister, T.A., Chouinard, P.Y., 2008. Digestion, ruminal fermentation, ciliate protozoal populations, and milk production from dairy cows fed cinnamaldehyde, quebracho condensed tannin, or Yucca schidigera saponin extract. J. Dairy Sci. 91, 4765-4777.

Boudon, A., Faverdin, P., Delagarde, R., Lamberton, P., Peyraud, J.L., 2007 Effects of rumen or duodenal glucose infusions on intake in dairy cows fed fresh perennial Ryegrass indoors. J. Dairy Sci. 90, 4397-4410.

Broderick, G.A., Kang, J.H., 1980. Automated simultaneous determination of ammonia and total amino acids in ruminal fluid and in vitro media. J. Dairy Sci. 63, 64-75.

Broderick, G.A., Wallace, R.J., Orskov, E.R., 1991. Control of rate and extent of protein degradation. In: Tsuda, T., Sasaki, Y., Kawashima, R. (Eds.) Proceedings of the 7th International Symposium on Ruminant Physiology. Physiological Aspects of Digestion and Metabolism in Ruminants, Academic Press Inc., San Diego, CA, pp. 541-592.

Calsamiglia, S., Busquet, M., Cardozo, P.W., Castillejos, L., Ferret, A., 2007 Invited review: essential oils as modifiers of rumen microbia fermentation. J. Dairy Sci. 90, 2580-2595.

Chen, X.B., Gomes, M.J., 1995. Estimation of Microbial Protein Supply to Sheep and Cattle Based on Urinary Excretion of Purine Derivatives: An Overview of the Technical Details. Rowett Research Institute Bucksburn, Aberdeen, UK.

Cowan, M.M., 1999. Plant products as antimicrobial agents. Clin. Microbiol. Rev. 12, 564-582.

Dehority, B.A., 2003. Rumen Microbiology. Nottingham University Press, Nottingham, UK.

Dschaak, C.M., Williams, C.M., Holt, M.S., Eun, J.S., Young, A.J., Min, B.R., 2011. Effects of supplementing condensed tannin extract on intake digestion, ruminal fermentation, and milk production of lactating dairy cows. J. Dairy Sci. 94, 2508-2519.

FASS, 2010. Guide for the care and use of agricultural animals in research and teaching, 3rd ed. Federation of Animal Science Societies, Champaign, IL.

Goel, G., Puniya, A.K., Aguliar, C.N., Singh, K., 2005. Interaction of gut microflora with tannins in feeds. Naturwissenschaften 92, 497-503.

Hess, H.D., Beuret, R.A., Lotscher, M., Hindrichsen, K.I., Machmüller, A., Carulla, J.E., Lascano, C.E., Kreuzer, M., 2004. Ruminal fermentation, methanogensis and nitrogen utilization of sheep receiveing tropical grass hay-concentrate diet offered with Sapindus saponaria fruits and Cratylia argentea foliage. J. Anim. Sci. 79, 177-189.

Hristov, A.N., McAllister, T.A., Van Herk, F.H., Cheng, K.J., Newbold, C.J., Cheeke, P.R., 1999. Effect of Yucca schidigera on ruminal fermentation and nutrient digestion in heifers. J. Anim. Sci. 77, 2554-2563.

Jami, E., Shabtay, A., Nikbachat, M., Yosef, E., Miron, J., Mizrahi, I., 2012 Effects of adding a concentrated pomegranate-residue extract to the ration of lactating cows on in vivo digestibility and profile of rumen bacterial population. J. Dairy Sci. 95, 5996-6005.

Jiménez-Peralta, F.S., Salem, A.Z.M., Mejia-Hernández, P., González-Ronquillo, M., lbarrán-Portillo, B., Rojo-Rubio, R., Tinoco-Jaramillo, J.L., 2011. Influence of individual and mixed extracts of two tree species on in vitro gas production kinetics of a high concentrate diet fed to growing lambs. Livest. Sci. 136, 192-200.

Makkar, H.P.S., 2000. Quantification of Tannins in Tree Foliage. A Laboratory Manual for the FAO/IAEA Co-ordinated Research Project on Use of Nuclear and Related Techniques to Develop Simple Tannin Assays for Predicting and Improving the Safety and Efficiency of Feeding Ruminants on Tanniniferous Tree Foliage. Joint FAO/IAEA of Nuclear Techniques in Food and Agriculture.Animal Production and Health Sub-Programme, FAO/IAEA Working Document, IAEA, Vienna, Austria.

Makkar, H.P.S., 2003. Effects and fate tannins in ruminant animals, adaptation to tannins, and strategies to overcome detrimental effects of feeding tannin-rich feeds. Small Rumin. Res. 49, 241-256.

Makkar, H.P.S., Sen, S., Blummel, M., Becker, K., 1998. Effects of fractions containing saponins from Yucca schidigera, Quillaja saponaria and Acacia auriculo formis on rumen fermentation. J. Agric. Food Chem. 46, 4324-4328.

Mirzaei-Aghsaghali, A., Maheri-Sis, N., Mansouri, H., Razeghi, M.E. Mirza-Aghazadeh, A., Cheraghi, H., Aghajanzadeh-Golshani, A., 2011. 
Evaluating potential nutritive value of pomegranate processing byproducts for ruminants using in vitro gas production technique. ARPN J. Agric. Biol. Sci. 6, 45-51.

Mueller-Harvey, I., 2006. Review, unraveling the conundrum of tannins in animal nutrition and health. J. Sci. Food Agric. 86, 2010-2037.

NRC, 2001. Nutrient Requirements of Dairy Cattle, 7th rev. ed. National Academy of Science, Washington, DC.

Nasri, S., Ben Salem, H., 2012. Effect of oral administration of Agave americana or Quillaja saponaria extracts on digestion and growth of Barbarine female lamb. Livest. Sci. 147, 59-65.

Oliveira, R.A., Narciso, C.D., Bisinotto, R.S., Perdomo, M.C., Ballou, M.A., Dreher, M., Santos, J.E.P., 2010. Effects of feeding polyphenols from pomegranate extract on health. Growth, nutrient digestion, and immunocompetence of calves. J. Dairy Sci. 93, 4280-4291.

Patra, A.K., Saxena, J., 2011. Exploitation of dietary tannins to improve rumen metabolism and ruminant nutrition. J. Sci. Food Agric. 91, 24-37.

Raghuvansi, S.K.S., Tripathi, M.K., Mishr, A.S., Chaturvedi, O.H., Prasad, R., Saraswat, B.L., Jakhmola, R.C., 2007. Feed digestion, rumen fermentation and blood biochemical constituents in Malpura rams fed a complete feed-block diet with the inclusion of tree leaves. Anim. Feed Sci. Technol. 71, 21-30.

Reed, J.D., 1995. Nutritional toxicology of tannins and related polyphenols in forage legumes. J. Anim. Sci. 73, 1516-1528.

Robertson, J.B., Van Soest, P.J., 1981. The detergent system of analysis. In: James, W.P.T., Theander, O. (Eds.), The Analysis of Dietary Fiber in Food, vol. 158. , Marcel Dekker, New York, NY, USA, Basel, Switzerland, pp. 123. (Chapter 9).

SAS, 2002. SAS User's Guide: Statistics. Ver 9.0. SAS Institute, Cary, NC, USA956.

Salem, A.Z.M., Olivares, M., Lopez, S., Gonzalez-Ronquillo, M., Rojoc, R., Camacho, L.M., Cerrillo, S.M.A., Mejia, H.P., 2011. Effect of natural extracts of Salix babylonica and Leucaena leucocephala on nutrient digestibility and growth performance of lambs. Anim. Feed Sci. Technol. 170, 27-34.

Shabtay, A., Eitam, H., Tadmor, Y., Orlov, A., Meir, A., Weinberg, P., Weinberg, Z.G., Chen, Y., Brosh, A., Izhaki, I., Kerem, Z., 2008. Nutritive and antioxidative potential of fresh and stored pomegranate industrial byproduct as novel beef cattle feed. J. Agric. Food Chem. 56, 10063-10070.

Shabtay, A., Nikbachat, M., Zenou, A., Yosef, E., Arkin, O., Sneer, O., Shwimmer, A., Yaari, A., Budmand, E., Agmond, G., Miron, J., 2012.
Effects of adding a concentrated pomegranate extract to the ration of lactating cows on performance and udder health parameters. Anim. Feed Sci. Technol. 175, 24-32.

Tamminga, S., Hobson, P.N., 1996. A review on environmental impacts of nutritional strategies in ruminants. J. Anim. Sci. 74, 3112-3124.

Tempelman, R.J., 2004. Experimental design and statistical methods for classical and bioequivalence hypothesis testing with an application to dairy nutrition studies. J. Anim. Sci. 82, 162-172.

Valadares, R.F.D., Broderick, G.A., Valadares Filho, S.C., Clayton, M.K., 1999. Effect of replacing alfalfa silage with high moisture corn on ruminal protein synthesis, estimated from excretion of total purine derivatives. J. Dairy Sci. 82, 2686-2696.

Van Keulen, V., Young, B.H., 1977. Evaluation of acid-insoluble ash as natural marker in ruminant digestibility studies. J. Anim. Sci. 26, 119-135.

Van Nevel, C.J., Demeyer, D.I., 1988. Manipulation of rumen fermentation, The Rumen Microbial EcosystemElsevier Science Publishing, New York, NY387-443.

Van Soest, P.J., 1994. Nutritional Ecology of the Ruminant. Cornell University Press, Ithaca, NY, USA.

Van Soest, P.J., Robertson, J.B., Lewis, B.A., 1991. Methods for dietary fiber, neutral detergent fiber, and nonstarch poly-saccharides in relation to animal nutrition. J. Dairy Sci. 74, 3583-3597.

Vasta, V., Nuddab, A., Cannas, A., Lanza, M., Priolo, A., 2008. Alternative feed resources and their effects on the quality of meat and milk from small ruminants. Anim. Feed Sci. Technol. 147, 223-246.

Vitti, D.M.S.S., Abdalla, A.L., Bueno, I.C.S., Silva Filho, J.C., Cota, C., Bueno, M.S., Noozella, E.F., Longo, C., Vieira, E.Q., Cabral Filho, S.L.S., Godoy, P.B., Mueller-Harvey, I., 2005. Do all tannins have similar nutritional effects? A comparison of three Brazilian fodder legumes. Anim. Feed Sci. Technol. 119, 345-361.

Wallace, R.J., McEwan, N.R., McIntosh, F.M., Teferedegne, B., Newbold, C.J., 2002. Natural products as manipulators of rumen fermentation. Asian-Australas. J. Anim. Sci. 15, 1458-1468.

Williams, A.G., Coleman, G.S., 1991. The Rumen Protozoa. Springer-Verlag, New York Inc., New York.

Yanez Ruiz, D.R., Moumen, A., Martin Garcia, A.I., Molina Alcaide, E., 2004. Ruminal fermentation and degradation patterns, protozoa population and urinary purine derivatives excretion in goats and wethers fed diets based on two-stage olive cake: effect of PEG supply. J. Anim. Sci. 85, 2023-2032. 